\title{
Article \\ Impact of the Cathode Layer Printing Process on the Performance of MEA Integrating PGM Free Catalyst
}

\author{
Pierre Toudret, Jean-François Blachot, Marie Heitzmann * * and Pierre-André Jacques * \\ CEA, LITEN, DEHT, LCP, University Grenoble Alpes, 17 Rue des Martyrs, F-38000 Grenoble, France; \\ pierre.toudret@cea.fr (P.T.); jean-francois.blachot@cea.fr (J.-F.B.) \\ * Correspondence: marie.heitzmann@cea.fr (M.H.); pierre-andre.jacques@cea.fr (P.-A.J.); \\ Tel.: +33-478-380-4402 (M.H.); +33-478-380-0699 (P.-A.J.)
}

Citation: Toudret, P.; Blachot, J.-F.; Heitzmann, M.; Jacques, P.-A. Impact of the Cathode Layer Printing Process on the Performance of MEA Integrating PGM Free Catalyst. Catalysts 2021, 11, 669. https:// doi.org/10.3390/catal11060669

Academic Editor: Sabrina Campagna Zignani

Received: 21 April 2021

Accepted: 22 May 2021

Published: 24 May 2021

Publisher's Note: MDPI stays neutral with regard to jurisdictional claims in published maps and institutional affiliations.

Copyright: (c) 2021 by the authors. Licensee MDPI, Basel, Switzerland. This article is an open access article distributed under the terms and conditions of the Creative Commons Attribution (CC BY) license (https:// creativecommons.org/licenses/by/ $4.0 /)$.
Abstract: In this work, platinum group metal (PGM) free-based cathode active layers were prepared using different printing techniques. The membrane electrode assemblies (MEAs) integrate a PGM free catalyst based on $\mathrm{Fe}, \mathrm{N}$ and $\mathrm{C}$ atoms at the cathode side. Scanning electron microscopy (SEM) images of MEA cross sections showed the strong impact of the fabrication process on the cathode structure, the porosity and the ionomer repartition. The MEAs were characterized in a $25 \mathrm{~cm}^{2}$ single cell using cyclic voltammetry under $\mathrm{H}_{2} / \mathrm{N}_{2}$. The performance of the MEAs and the double layer capacity of the cathodes were also shown to be linked to the process used. The comparison of the electrochemical accessible surface of the catalyst and of its surface area (SBET) led to the determination of a utilization factor. The coated membrane (CCM) made using the decal transfer process gives the best performances.

Keywords: PGM free catalyst; printing process; membrane electrode assembly; cathode structure

\section{Introduction}

Fuel cell is an alternative power generation technology that converts chemical energy into electricity and heat through an electrochemical reaction. It has gained widespread attention in research and development into ecofriendly energy source. In that field, proton exchange membrane fuel cell (PEMFC) is a promising energy conversion device for automotive application thanks to its high efficiency, high power density and zero pollutant emissions [1-3].

One major limitation of PEFMCs for commercial applications is its dependency to the costly and scarce platinum. This metal is used as catalyst for both the oxygen reduction reaction (ORR) and hydrogen oxidation reaction (HOR) that occur at the cathode and anode respectively. Furthermore, the increase of mining extraction of $\mathrm{Pt}$ may lead to social and environmental consequences [4].

To reduce the environmental impact and the cost of the production of PEMFC, it is therefore mandatory to reduce its dependency on Pt. The decrease of Pt loadings in the membrane electrode assemblies (MEAs) has focused attention in recent decades, but the transition to a next-generation PEMFC using Platinum Group Metals-free (PGM-free) catalysts at the cathode side is needed. The targets for performance and durability are similar to those defined currently with Pt. For example, both the European and DoE target for catalyst activity is $44 \mathrm{~mA} / \mathrm{cm}^{2}$ at $0.9 \mathrm{~V}$, while for MEA performance in a single cell, the European target is $600 \mathrm{~mA}$ at $0.7 \mathrm{~V}$ under harmonized European testing conditions [3,5]. The achievement of such challenging targets need work on both electrocatalyst optimization and catalyst layer structuration.

Among all the families of PGM free catalysts reported in the literature, such as $\mathrm{Ru}$ based chalcogenide [6], cobalt based chalcogenides [7], and supported cobalt based pyrite [8], the M/N/C material was reported as the most active for ORR in acidic media [9]. 
$\mathrm{M}$ can be $\mathrm{Fe}, \mathrm{Ni}, \mathrm{Co}$, and $\mathrm{Mn}$, but $\mathrm{Fe}$ based materials were characterized as the most active [10-12] and are commonly named as $\mathrm{FeN}_{X} / \mathrm{C}$ catalysts. For this last family of material, the debate on the nature of the active center, either embedded Fe particles surrounded by a carbon shell [13] or a Fe single atom surrounded by $\mathrm{N}$ atoms [14], was recently summarized by Asset and Atanassov [15]. In the last decade, in order to improve their activity, numerous of these $\mathrm{FeNx} / \mathrm{C}$ catalysts have been obtained using different preparation pathways. The activity of these newly developed PGM materials is often characterized using ex situ techniques, such as the rotating disk electrode (RDE) [16]. However, their integration into the cathode active layer of the MEA is far less commenly studied and few papers report on the impact of the catalyst layer (CL) structure of the PGM free cathode on the MEA performance [17-19]. In comparison, for the Pt based CL, the link between the electrode structure, the transport mechanisms and the MEA performance has been extensively studied [20]. PGM-free catalysts need to be processed in thicker layers because of their low ORR activity compared to PGM catalysts [21]. Threshold values of $\approx 3-5 \mu \mathrm{m}$ (PGM) and 60-100 $\mu \mathrm{m}$ (PGM-free) are required for the cathode active layer thickness [17,22,23] For these thick PGM-free cathodes, the active layer morphology, led by the fabrication process and the nature of the integrated catalyst, has an important impact on fuel cell performance by affecting mass transport $[17,24,25]$ and water management $[20,25,26]$.

MEA are made by thanks to two different methods: the first catalyst-coated membrane (CCM), corresponds to CL deposited on the membrane and the second catalyst-coated backing (CCB), is obtained when CL is deposited on the gas diffusion layer (GDL) to form a gas diffusion electrode (GDE). Several CCM fabrication methods exist, including doctor blade, screen-printing, air spraying, ultrasonic spray deposition and ink jet printing. CL can be deposited directly on the membrane or on an inert substrate, which is then used to carry out a transfer by decal. The CCM is integrated into a MEA by sandwiching it between GDL; in our case the GDL integrates a carbon microporous layer (MPL). In the case of MEA made with the CCB technique, GDE are assembled with the membrane, either including a hot pressing step, or not [17]. The MEA were prepared either by assembling GDE and membrane or by assembling GDL and CCM.

In this study, we therefore reported the impact of the MEA preparation technique on both the structure of the cathode active layer and the performance of the MEA, integrating a PGM free catalyst for ORR.

\section{Results and Discussion}

The Figure 2a-c shows performance of the obtained MEA; only one polarization curve is reported for each preparation technique but each experiment has taken place twice. Polarization curves bring out the difference in performance between the MEAs, despite a similar composition and loading of the non-noble catalyst. The only difference lies in the fabrication method that impacts the structure of the cathode catalyst layer. The MEA based on CCM gave better performance than the MEA based on CCB, whatever the printing process. That is especially true for condition 3 where the probability of water condensation is higher due to higher inlet pressure and lower air stoichiometry. In this condition we can observe a flooding of the MEA at around $0.07 \mathrm{~A} / \mathrm{cm}^{2}$. The active layers printed using a bar coater gave better performance than those printed using the spray coater. The MEA prepared by spraying the cathode active layer directly onto the membrane gave the poorest performance. 


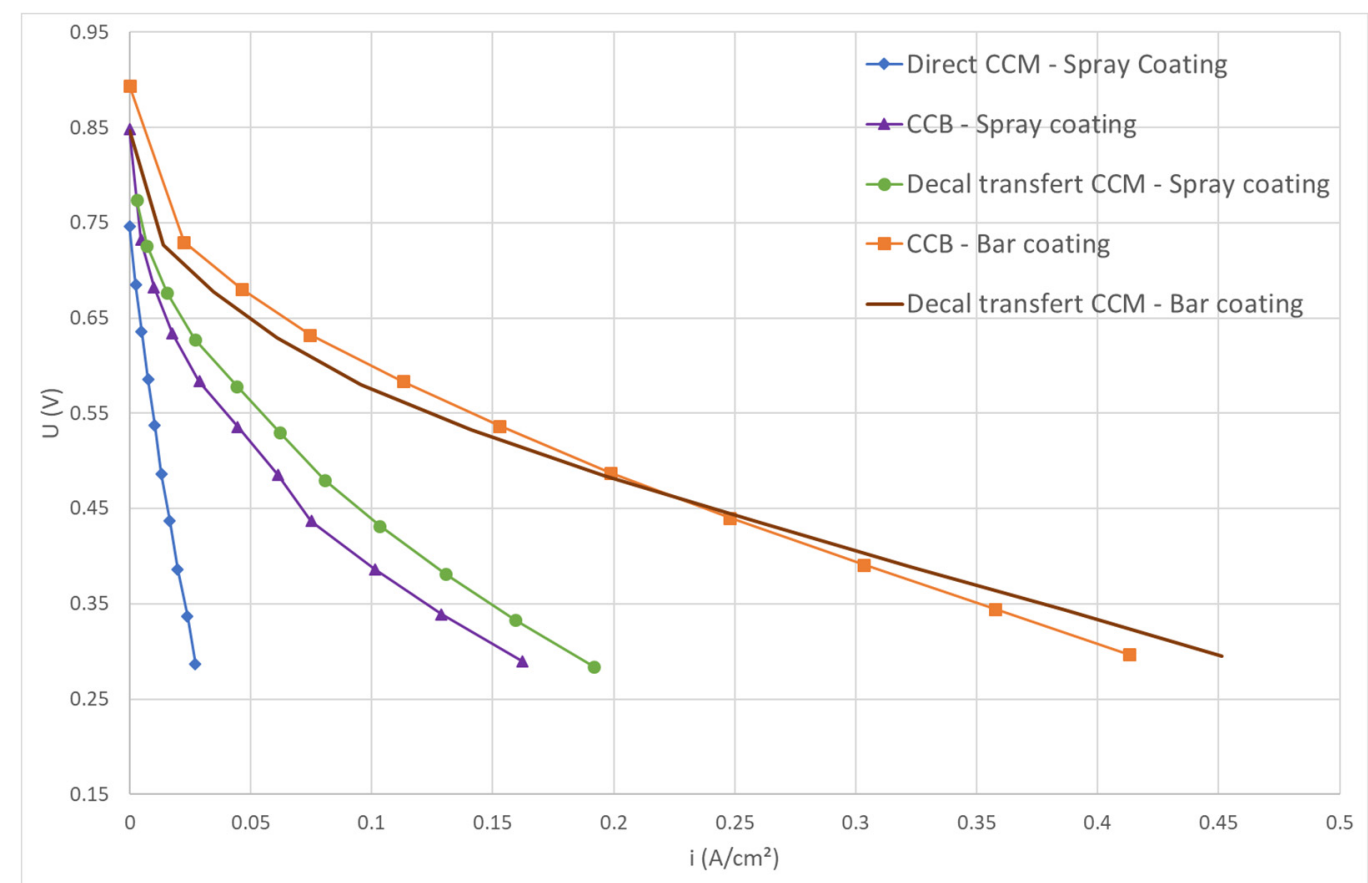

(a)

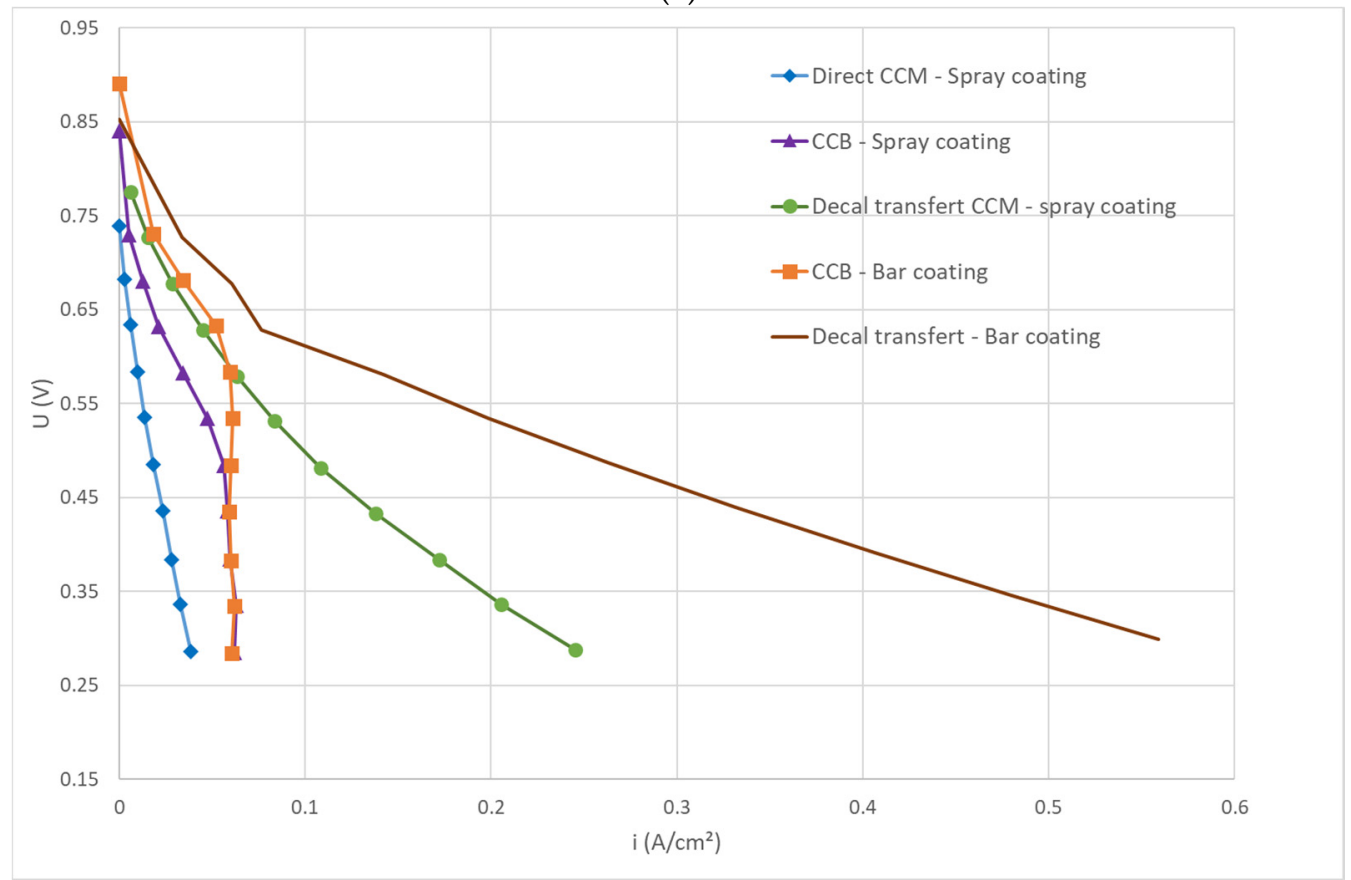

(b)

Figure 1. Cont. 


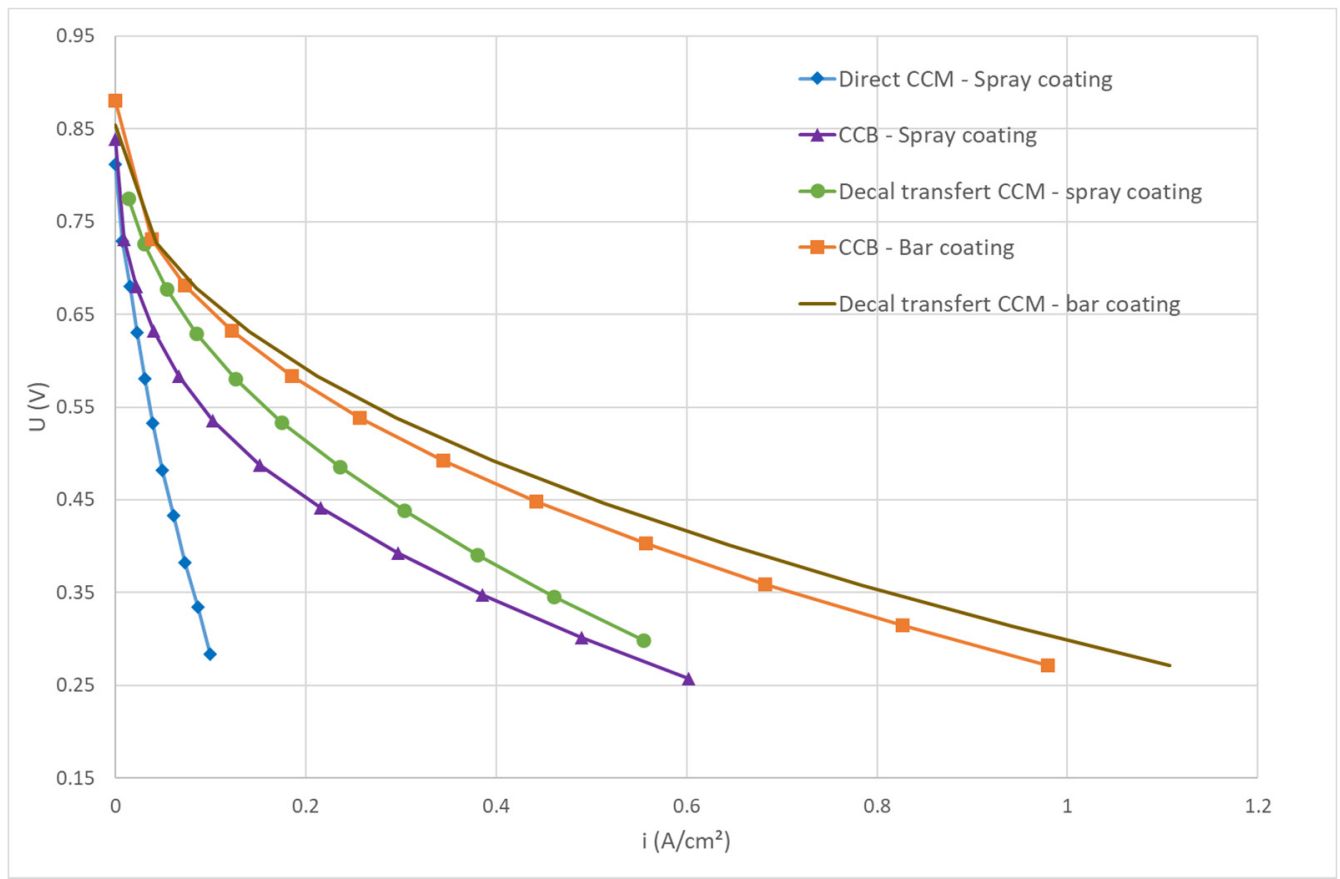

(c)

Figure 2. Polarization curves obtained for MEA made by different processes. (a) Condition $2\left(\mathrm{H}_{2} /\right.$ air $): 80{ }^{\circ} \mathrm{C} ; 50 \% \mathrm{RH} ; 1.5 \mathrm{~b}$; St: $1.2-2$; (b) Condition $3\left(\mathrm{H}_{2} /\right.$ air): $80{ }^{\circ} \mathrm{C} ; 50 / 30 \% \mathrm{RH} ; 2.5 / 2.3$ b; St: $1.3 / 1.5$; (c) Condition $5\left(\mathrm{H}_{2} / \mathrm{O}_{2}\right): 80{ }^{\circ} \mathrm{C} ; 50 \% \mathrm{RH} ; 1.5$ b; St: $1.2-5$.

The CV made on this MEA are reported in Figure 3, and a large difference in the double layer capacitance (DLC), depending on the preparation techniques, can be pointed out. Serov et al. [27] showed that the higher the DLC, the higher the performance. As the PGM free catalysts are composed mostly of carbon, they can be considered as activated carbon. Under $\mathrm{N}_{2}$, there is no ORR occurring at the cathode side of the MEA. Furthermore, the PGM free catalysts are not active for HOR and no crossover current can be detected. The CV reported in Figure 3 are not corrected and are naturally centered on the $\mathrm{Y}$ axis, showing that $\mathrm{H}_{2}$ is not oxidized on the PGM free catalyst, based on Fe/N/C. Therefore, we can assume that, under $\mathrm{N}_{2}$, the cathode side of the MEA works as the positive electrode of a capacitor [17]. The surface of the double layer can be estimated considering an electrical double layer capacity equal to $0.2 \mathrm{~F} \cdot \mathrm{m}^{-2}$ and Equation (1). This surface represents the surface of the carbon, electrically connected and in contact with the electrolyte, i.e., the electro-available surface (EAS). EAS is calculated according to the Equation (2). A utilization factor (Uf) representing the fraction of the catalyst surface available for the ORR (EAS) on the total catalyst specific surface area $\left(\mathrm{S}_{\mathrm{BET}}\right)$ can be calculated (Equation (3)).

$$
\begin{gathered}
\mathrm{C}=\frac{\mathrm{I}}{(\mathrm{dv} / \mathrm{dt})} \\
\text { EAS }=\frac{\mathrm{C} / \mathrm{c}}{\mathrm{Sgeo} * \text { Loading }} * 1000 \\
\mathrm{Uf}=\frac{\mathrm{EAS}}{\mathrm{S}_{\mathrm{BET}}}
\end{gathered}
$$

with:

$\mathrm{C}$ in $\mathrm{F}$, I current in $\mathrm{mA}$ corresponding to $\left(\mathrm{I}^{+}+\mathrm{I}^{-} / 2\right)$ and $(\mathrm{dV} / \mathrm{dt})$ in $\mathrm{mV} / \mathrm{s}$.

EAS in $\mathrm{m}^{2} / \mathrm{g}$;

c double layer capacity in $\mathrm{F} \cdot \mathrm{m}^{-2}$ (we assume $\mathrm{c}=0.2 \mathrm{~F} \cdot \mathrm{m}^{-2}$ );

$\mathrm{S}_{\text {geo }}$ : geometrical surface of the MEA in $\mathrm{cm}^{2}$; 
Loading: total catalyst loading of the cathode in $\mathrm{mg}_{\mathrm{cat}} / \mathrm{cm}^{2}$;

Uf in $\%$.

Table 1. EAS and Uf calculated for each printing technique used, with $\mathrm{c}=0.2 \mathrm{~F} \cdot \mathrm{m}^{-2}$ and $\mathrm{S}_{\mathrm{BET}}=520 \pm 20 \mathrm{~m}^{2} / \mathrm{g}$.

\begin{tabular}{|c|c|c|c|c|c|}
\hline Coating Technique & $\begin{array}{c}\text { Loading } \\
\left(\mathrm{mgcat} / \mathrm{cm}^{2}\right)\end{array}$ & $\mathrm{I}^{+}+\mathrm{I}^{-}(\mathrm{mA})$ & $\operatorname{EAS}\left(\mathrm{m}^{2} / \mathrm{g}\right)$ & $\begin{array}{c}\text { Average EAS } \\
\left(\mathrm{m}^{2} / \mathrm{g}\right)\end{array}$ & Uf $(\%)$ \\
\hline $\begin{array}{l}\text { Direct CCM-spray } \\
\text { coating-1 }\end{array}$ & 2 & 47 & 47 & \multirow[t]{2}{*}{$63 \pm 16$} & \multirow[t]{2}{*}{$12 \pm 3$} \\
\hline $\begin{array}{c}\text { Direct } C \mathrm{CM}-\text { spray } \\
\text { coating-2 }\end{array}$ & 2 & 78 & 78 & & \\
\hline CCB-Spray coating-1 & 2 & 112 & 112 & \multirow{2}{*}{$116 \pm 14$} & \multirow{2}{*}{$22 \pm 3$} \\
\hline CCB-Spray coating-2 & 2 & 119 & 119 & & \\
\hline $\begin{array}{c}\text { Decal transfer } \\
\text { CCM-Spray coating-1 }\end{array}$ & 2 & 189 & 189 & \multirow{2}{*}{$237 \pm 48$} & \multirow{2}{*}{$46 \pm 9$} \\
\hline $\begin{array}{c}\text { Decal transfer } \\
\text { CCM-Spray coating-2 }\end{array}$ & 1.17 & 167 & 285 & & \\
\hline CCB-Bar coating-1 & 2 & 510 & 510 & \multirow{2}{*}{$489 \pm 21$} & \multirow{2}{*}{$94 \pm 4$} \\
\hline $\mathrm{CCB}-$ Bar coating-2 & 2.8 & 654 & 467 & & \\
\hline $\begin{array}{c}\text { Decal transfer } \\
\text { CCM-Bar coating-1 }\end{array}$ & 2.3 & 460 & 400 & \multirow{2}{*}{$411 \pm 11$} & \multirow{2}{*}{$79 \pm 4$} \\
\hline $\begin{array}{c}\text { Decal transfer } \\
\text { CCM-Bar coating-2 }\end{array}$ & 2.3 & 485 & 422 & & \\
\hline
\end{tabular}

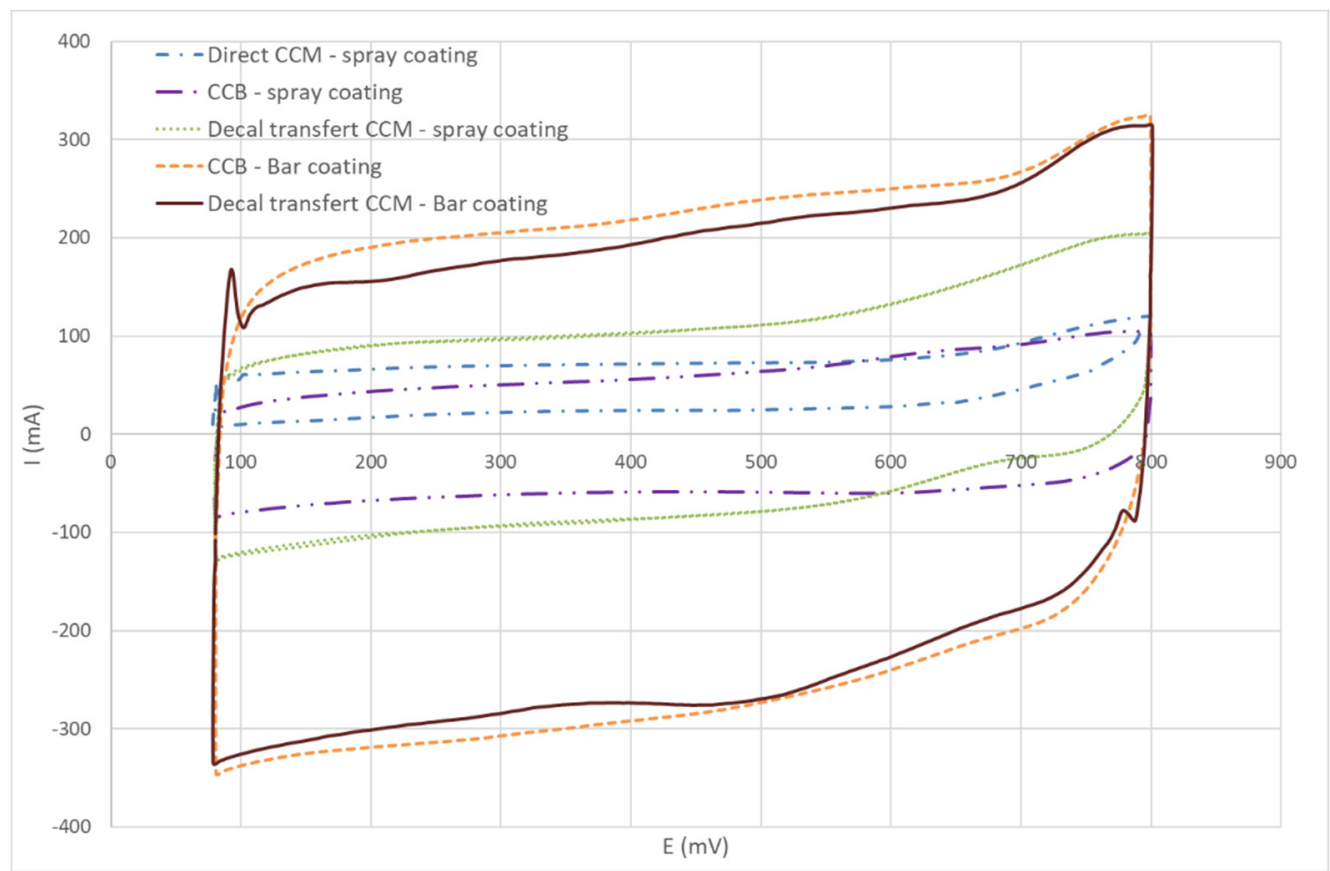

Figure 3. Cyclic voltammetry under $\mathrm{H}_{2} / \mathrm{N}_{2} ; 80{ }^{\circ} \mathrm{C} ; 100 \% \mathrm{RH}$ and 1.5 bara pressure (CV made on MEA-1 in Table 1).

The Uf was calculated for each tested printing technique. The data reported in Table 1 are the average value of two distinct experiments (MEA-1 and MEA-2). The values of Uf are consistent with the performance of the MEA at low current. Indeed, the higher the Uf, the higher the MEA performance.

It can also be noticed that the performance of the CCM made using bar coating is better than the CCB made using the same process at a current higher than $0.2 \mathrm{~A} / \mathrm{cm}^{2}$ under air. The Uf is, therefore, not the only indicator for designing an optimal CL structure. 


\section{Structural Characterization}

The obtained SEM images allow us to compare the impact of the fabrication process on the structure of the MEA and especially on the cathode CL structure. The Figure 4a shows the SEM image of the cross section of the MEA obtained due to a direct spraying of the cathode CL on the membrane. The small swelling of the membrane observed during the printing of the CL can explain its non-flat shape. Figure $4 b, c$ represent the SEM images of the cross section of the MEA obtained by printing the cathode CL using the ultrasonic spray, as for Figure 4a. It can be seen that this process results in a dense cathode CL and the carbon particles seem flooded in ionomer and isolated from each other. Figure $4 \mathrm{~d}$,e represent the SEM images of the cross section of MEA obtained using the bar coating process. This process leads to higher porosity of the cathode $\mathrm{CL}$, maintained even after the hot pressing step, as for CCM made by the decal technique. Table 2 summarizes the cathode active layer thickness measured by SEM for all process configurations.

As the MEAs have the same composition, the thinner the MEA, the denser it is. The ranking of the measured thickness gives the porosity ranking. This difference of morphology is consistent with the Uf previously calculated and explains the differences in performance measured by polarization curves. The thickness of the cathode catalyst layer, the CL porosity and the performance of MEA follow the same ranking.

Nevertheless, the CCM made using bar coating presents higher performances than the CCB made using bar coating even if the CCB has a better Uf. The porosity of the CCM is about two times higher than that of CCB. This highlights the high sensitivity of the MEA performance to the porosity of the catalyst layer. In conclusion, for the CCB technology made using the bar coating process, although most of the catalysts are electrically connected and in contact with the electrolyte, the porosity of the CL is not optimal, which might impact the gas diffusion and/or the water removal. This could explain the observed sharp decline in polcurve of the MEA based on $\mathrm{CCB}$, which is the signature of the flooding of the CL in condition 3. As this sharp decline is seen for the 2 MEAs based on CCB, another hypothesis, such as the differences in the interface between CL and GDL for CCB and CCMm could be assumed. However, further studies would be needed to arrive at a conclusion.

For this reason, we recorded SEM images using higher brightness for the CCM made by bar coating (Figure 5). As there is no Pt at the cathode side, it is easier to discriminate the Nafion ${ }^{\circledR}$ and the carbon. The ionomer appears brighter, the carbon grey and the pores black. The ionomer is homogeneously dispersed and there is no excess of ionomer able to close porosities. This structuration allows a better gas diffusion through the CL. Liu et al. showed that the water should condensate in large pores and that the water formed inhibits the gas diffusion into the CL [25]. Nevertheless, for CCM made using bar coating, it is to be noticed that the pore size distribution seems homogeneous with a network of small pores from the membrane to the GDL, which should provide a structural advantage for better water management. 


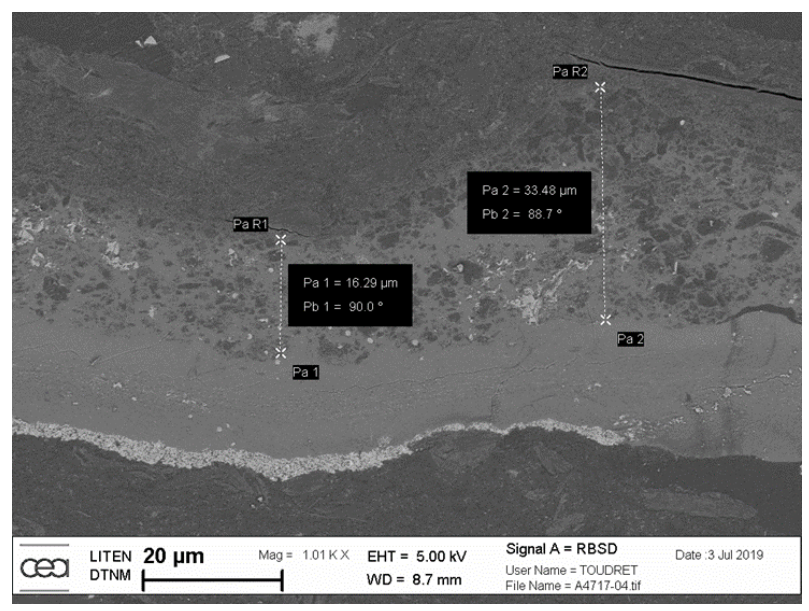

(a) Direct CCM-Spray coating Thickness $=18 \pm 3 \mu \mathrm{m}$

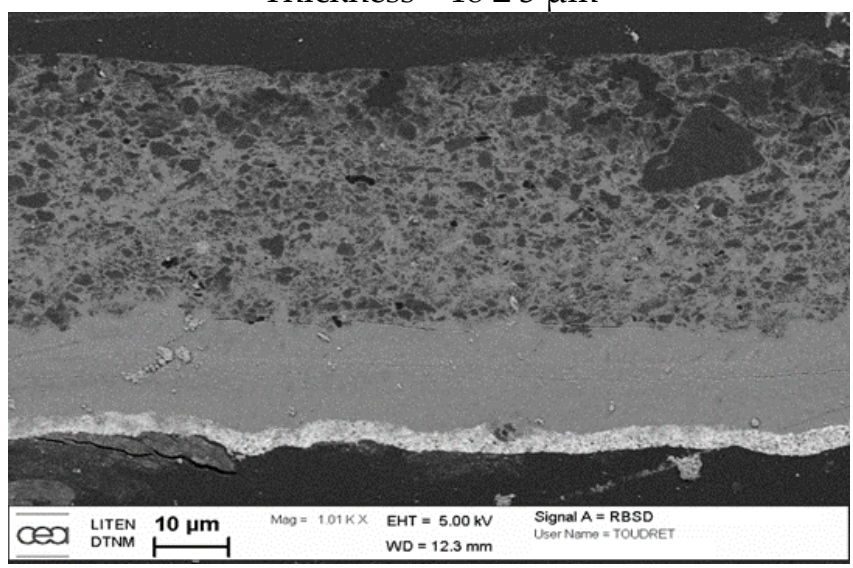

(c) Decal transfer CCM-spray coating Thickness $=40 \pm 3 \mu \mathrm{m}$

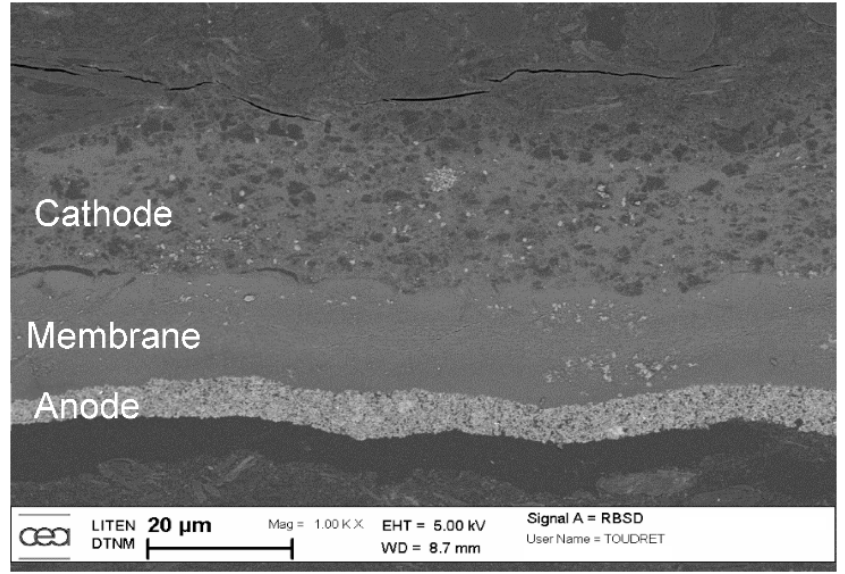

(b) CCB - spray coating

Thickness $=26 \pm 9 \mu \mathrm{m}$

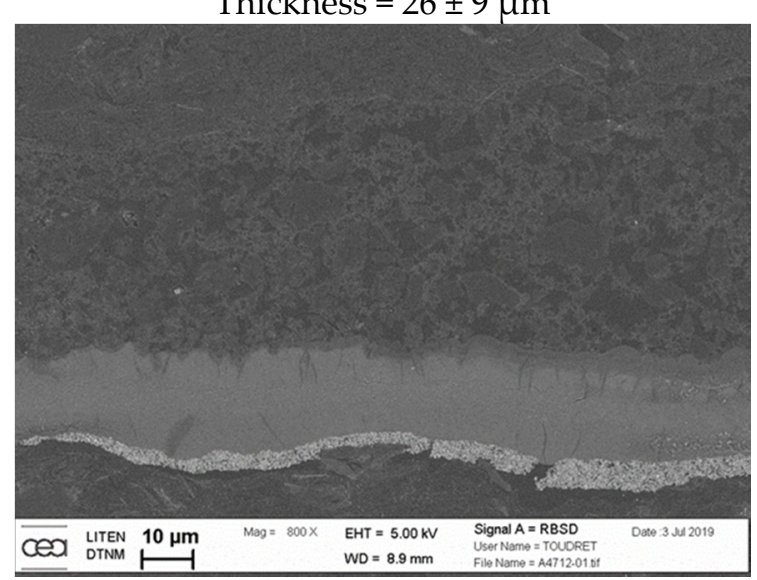

(d) $\mathrm{CCB}-$ Bar coating

Thickness $=50 \pm 10 \mu \mathrm{m}$

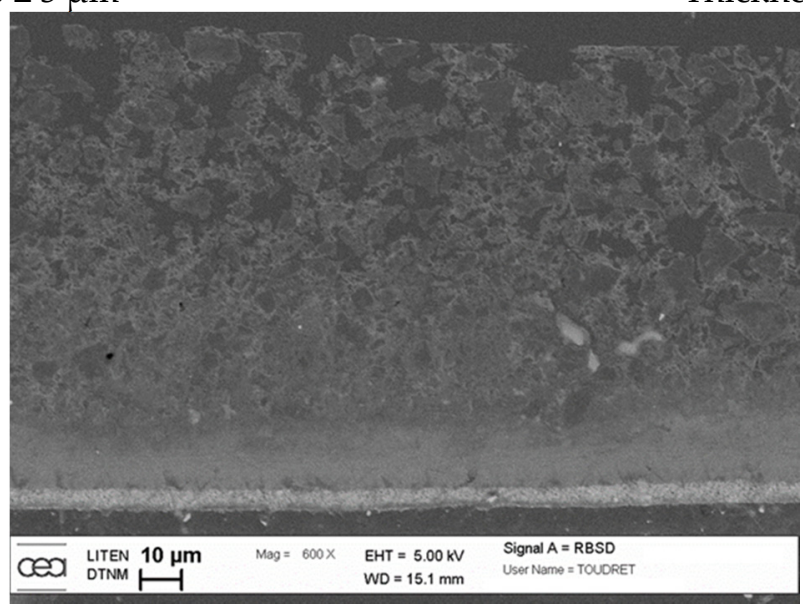

(e) Decal transfer CCM-Bar coating

Thickness $=90 \pm 3 \mu \mathrm{m}$

Figure 4. Comparison of process fabrication of CEA Pajarito MEA (anode: TKK 0.1-0.2 $\mathrm{mgPt} / \mathrm{cm}^{2}$; cathode: Pajarito 2 $\left.\mathrm{mg} / \mathrm{cm}^{2}\right)$. (a-e): SEM observation of MEA cross section, process used and cathode active layer thickness. 
Table 2. Thickness of cathode catalyst layer.

\begin{tabular}{ccc}
\hline MEA & Cathode Average Thickness $(\boldsymbol{\mu m})$ & Cathode Thickness Variation $(\mu \mathbf{m})$ \\
\hline Direct CCM-spray coating & 18 & 3 \\
CCB-Spray coating & 26 & 9 \\
Decal transfer CCM-Spray coating & 40 & 3 \\
CCB-Bar coating & 50 & 10 \\
Decal transfer CCM-Bar coating & 90 & 3 \\
\hline
\end{tabular}

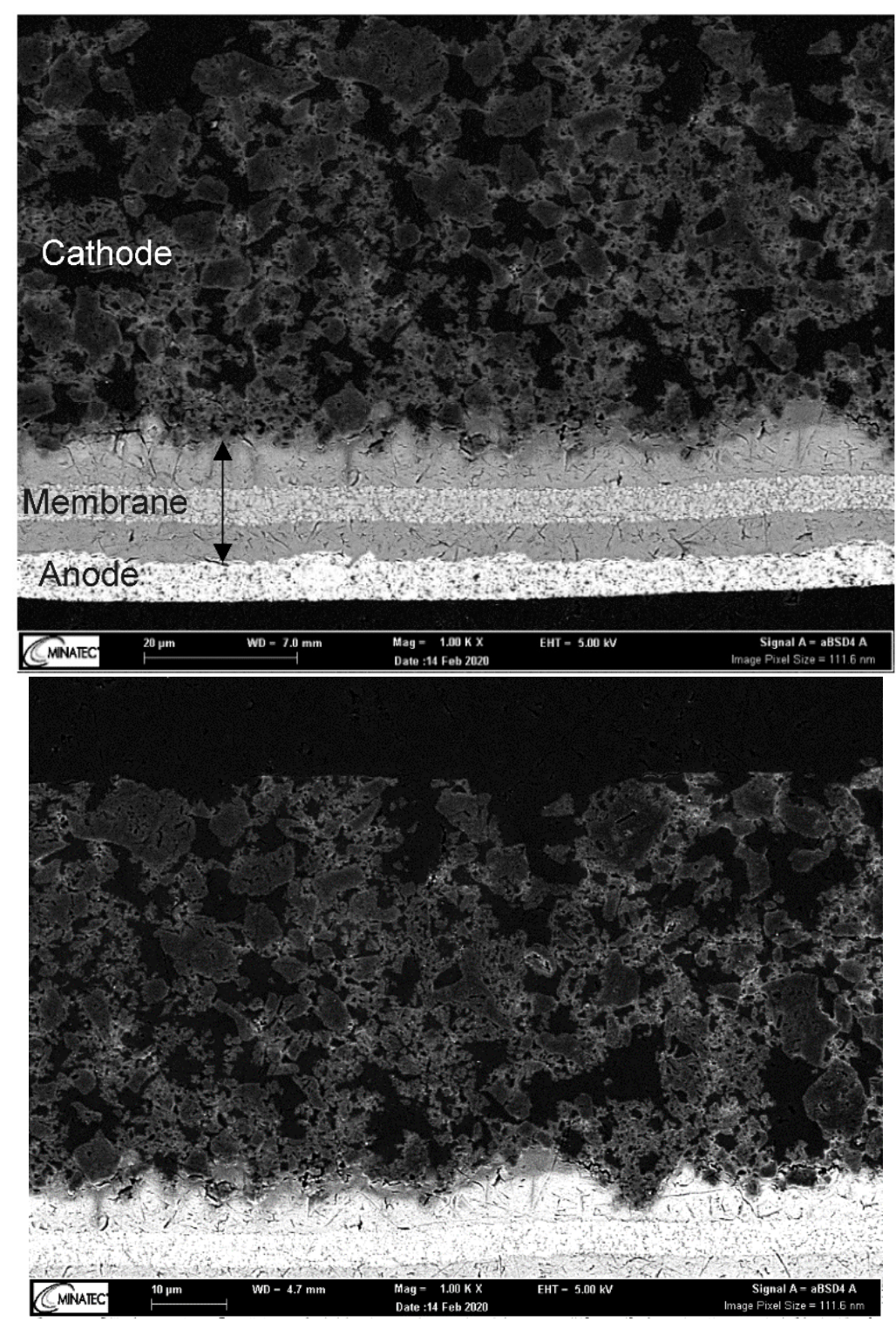

Figure 5. SEM images (high brightness mode) of cross sections of CCM made using bar coating; the scale bar is $20 \mu \mathrm{m}$ (up) and $10 \mu \mathrm{m}$ (down).

\section{Experimental Methpd}

4.1. MEA Preparation

The 3D mesoporous structured PGM-free catalyst (PMF-011904) from Pajarito Powders Company was integrated into the cathode catalyst layers of the MEAs by different methods. This catalyst is based on a FeNx/C moiety integrated in a carbon matrix. Three kinds of MEA preparation (Direct CCM, Decal transfer CCM and CCB) and two types of catalyst ink coating process (spray coating, bar coating) were tested. MEAs were prepared using a 
poly-fluorosulfonic acid (PFSA) based membrane reference MX 820.15 from Gore, $\mathrm{Pt} / \mathrm{C}$ catalyst, reference TEC10V50E, from TKK for the anode and the GDL, reference H23C7, from Freudenberg. In order to point out the impact of process fabrication on the membrane integrity, a thin membrane $(15 \mu \mathrm{m})$ was chosen.

To obtain the cathode catalyst layer, two inks were prepared by mixing catalyst, ionomer (Nafion ${ }^{\circledR}$ D2020) and solvents, the first specified for spray coating with a dry extract of $2 \%$, and the second for bar coating with a dry extract of $19 \%$. The ionomer at carbon ratio $(\mathrm{I} / \mathrm{C})$ was fixed to 0.89 for each process. Considering the weight of the carbon as equal to the weight of catalyst, this ratio had already been demonstrated as a good compromise to show enough ionomer penetration in the catalyst particles without blocking the macropores. [20,26]. Catalyst inks are coated on several substrates (GDL or inert substrate) using spray coating or bar coating and dried to obtain the cathode catalyst layer.

For the anode side, the ink was deposited using bar coating on different substrates (GDL or inert substrate) to obtain the anode catalyst layer after drying.

Spray coating was performed thanks to an automated ultrasonic spray apparatus (Exactacoat from Sono-Tek) operating at $120 \mathrm{kHz}$. For this type of coating, several layers were superimposed until the targeted loading was achieved.

Bar coating was performed thanks to Elcometer 4340 and a blade in one pass.

The catalyst loading was fixed at $2 \mathrm{mg}$ cat $/ \mathrm{cm}^{2}$ at the cathode, in order to limit the thickness and to reduce the transport losses. The platinum loading on the anode was $0.1 \mathrm{mg}_{\mathrm{Pt}} / \mathrm{cm}^{2}$. Figure 6 describes the different types of process used in this study.

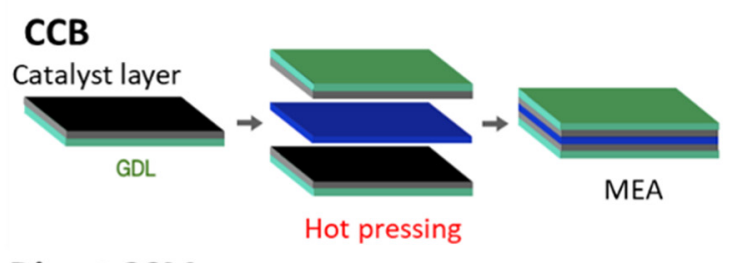

\section{Direct CCM}

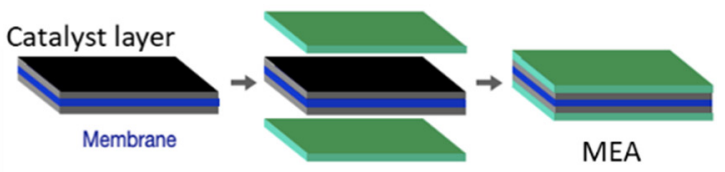

\section{Decal transfer CCM}

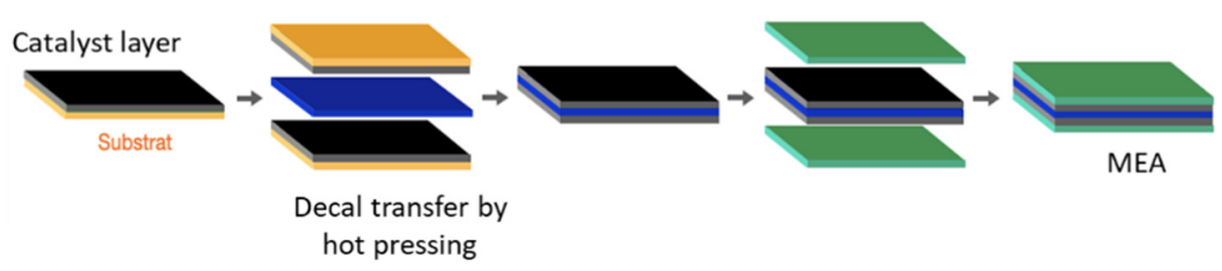

Figure 6. Schematic description of the different processes.

For each technique, at least two MEAs have been prepared and electrochemical characterizations performed twice. For the MEA fabrication for the second set of experiments, all the fabrication steps, including ink preparation, were repeated. Similar polarization curves were obtained for the two sets of experiments.

\subsubsection{Direct CCM Method}

For direct CCM preparation, the anode catalyst layer was first printed using bar coating on a PTFE transfer substrate. Then, this anode catalyst layer was transferred onto the membrane using hot pressing. The cathode catalyst layer was coated directly onto 
the other side of the membrane using spray coating. GDL was added during the single cell assembly.

\subsubsection{Decal Transfer CCM Method}

For decal transfer CCM preparation, anode and cathode catalyst layers were coated and dried on a PTFE based transfer substrate. Both catalyst layers were simultaneously transferred on the membrane using hot pressing. GDL was added during the single cell assembly. The cathode CL was printed using either spray coating or bar coating process.

\subsubsection{CCB Method}

For CCB preparation, anode and cathode catalyst layers were coated on a GDL. Both GDLs were hot pressed on the membrane to obtain a MEA. The cathode CL was printed either using a spray coating or bar coating process.

\subsection{Fuel Cell Tests}

The single cell tests were performed thanks to a Green Light (GL-40) test station coupled with a potentiostat Reference $3000^{\mathrm{TM}}$ from Gamry Instrument. The used graphite monopolar plates present an active area of $25 \mathrm{~cm}^{2}$. The flow field is a single serpentine presenting a square shape. Both the channel and the landing have a width of $1 \mathrm{~mm}$. The polarization curves were recorded under voltage control with first a voltage decrease from $0.775 \pm 0.001 \mathrm{~V}$ to $0.285 \pm 0.001 \mathrm{~V}$ and then a voltage increase from $0.285 \pm 0.001 \mathrm{~V}$ to $0.725 \pm 0.001 \mathrm{~V}$, with a last step at $0 \mathrm{~A}$, but with the electrical load still connected. The voltage was controlled by steps of $50 \pm 1 \mathrm{mV}$. Each voltage step was maintained for $300 \mathrm{~s}$, the current value was recorded every $2 \mathrm{~s}$ and the reported data are the averaged value on the 20 last seconds of each step. The curves from low to high voltages are reported. Before each polarization, the cell was maintained for $30 \mathrm{~min}$ at $775 \mathrm{mV}$ under the conditions corresponding to the polarization curve. The different operating conditions used are described in Table 3. When the gas flows were controlled by stoichiometry, a minimum flow corresponding to $2 \mathrm{~A}$ was maintained. The pressure was controlled at the inlet of the cell, and the absolute value is reported. The relative humidity was managed by boilers. The conditioning step was performed by voltage cycling corresponding to steps of $775 \mathrm{mV}$, $585 \mathrm{mV}$ and $390 \mathrm{mV}$ with a duration of $180 \mathrm{~s}$ for each step. The total conditioning duration is $1 \mathrm{~h}$, starting and finishing with a step at $775 \mathrm{mV}$. The OCV is recorded at the beginning of the test with a disconnected electrical load under operating condition corresponding to the condition 1 . At the end of each fuel cell test, cyclic voltammograms were recorded at $50 \mathrm{mV} / \mathrm{s}$ between 0.08 and $0.8 \mathrm{~V}$ vs. RHE, the $\mathrm{CV}$ were made at $80^{\circ} \mathrm{C}, 100 \% \mathrm{RH}$ and 1.5 bara pressure at both sides as shown on the sixth line of the Table 3 . The cell was flushed at least for $30 \mathrm{~min}$ with $\mathrm{H}_{2}$ at the anode and $\mathrm{N}_{2}$ at the cathode before recording the $\mathrm{CV}$.

Table 3. Fuel cell test conditions.

\begin{tabular}{|c|c|c|c|c|c|c|c|c|c|c|c|}
\hline \multirow[b]{2}{*}{ Condition } & \multirow{2}{*}{$\begin{array}{c}\text { Cell } \\
\text { Temperature } \\
\left({ }^{\circ} \mathrm{C}\right)\end{array}$} & \multicolumn{5}{|c|}{ Anode } & \multicolumn{5}{|c|}{ Cathode } \\
\hline & & Gas & RH (\%) & $\begin{array}{c}\text { Pressure } \\
\text { (Bara) }\end{array}$ & $\begin{array}{c}\text { Flow } \\
(\mathrm{mL} / \mathrm{min})\end{array}$ & Stoichiometry & Gas & RH (\%) & $\begin{array}{c}\text { Pressure } \\
\text { (Bara) }\end{array}$ & $\begin{array}{c}\text { Flow } \\
(\mathrm{mL} / \mathrm{min})\end{array}$ & Stoichiometry \\
\hline 1 & 80 & $\mathrm{H}_{2}$ & 80 & 1.5 & 522 & - & Air & 80 & 1.5 & 1243 & - \\
\hline 2 & 80 & $\mathrm{H}_{2}$ & 50 & 1.5 & - & 1.2 & Air & 50 & 1.5 & - & 2 \\
\hline 3 & 80 & $\mathrm{H}_{2}$ & 50 & 2.5 & - & 1.3 & Air & 30 & 2.3 & - & 1.5 \\
\hline 4 & 80 & $\mathrm{H}_{2}$ & 50 & 1.5 & - & 1.2 & Air & 50 & 1.5 & - & 2 \\
\hline 5 & 80 & $\mathrm{H}_{2}$ & 50 & 1.5 & - & 1.2 & $\mathrm{O}_{2}$ & 50 & 1.5 & - & 5 \\
\hline 6 & 80 & $\mathrm{H}_{2}$ & 100 & 1.5 & 150 & - & $\mathrm{N}_{2}$ & 100 & 1.5 & 400 & - \\
\hline
\end{tabular}

\subsection{Scanning Electron Microscopy (SEM)}

SEM observations were conducted using a field emission gun scanning electron microscope (FEG-SEM) Leo 1530 from Zeiss (Oberkochen, Germany), with an accelerating voltage of $5 \mathrm{kV}$ and a Rutherford backscattering detector RBSD. This detector generates a better contrast between each part of the observed samples. Cross-sections of MEAs were 
cut in the center zone, embedded into epoxy-resin and polished, after the electrochemical characterization in the single cell test. The images presented in this paper were produced one day after polishing.

\section{Conclusions}

This study shows the high sensitivity of the catalyst layer structure in the performance of cathode active layers integrating a PGM-free catalyst for ORR. We calculated a utilization factor (Uf) to evaluate the quality of the catalyst in the active layer, which can correspond to the roughness factor commonly used to study a conventional $\mathrm{Pt} / \mathrm{C}$ catalyst. We demonstrate that the Uf is a relevant parameter to qualify cathode CL, but the specification of porosity is also mandatory for better understanding of MEA performances.

We established a link between the technique used to print the cathode catalyst layer, the morphology of the cathode and the electrochemical performance of the MEAs. We showed that CCM integrating a PGM free catalyst can be obtained at the cathode side with better performances than CCB. This is of great importance for further selection of best GDL for a PGM-free MEA, as the same CCM technology could be used for different tests.

We also strongly recommend the use of this Uf to benchmark PGM free catalysts obtained from different suppliers or by different synthesis routes.

Author Contributions: P.T. performed the experiments, P.T., M.H., J.-F.B. and P.-A.J. analyzed the data, P.T. performed SEM analysis. P.T., P.-A.J., J.-F.B. and M.H. wrote and revised the paper. All authors have read and agreed to the published version of the manuscript.

Funding: The research leading to these results has received funding from the European Commission H2020 program (PEGASUS project Grant $\mathrm{N}^{\circ}:$ 779550).

Acknowledgments: The Authors thanks the European Commission H2020 program for having this work under the project PEGASUS (Grant $\mathrm{N}^{\circ}$ : 779550) and the Pajarito Powder Company for having kindly supply the PGM free catalyst.

Conflicts of Interest: The authors declare no conflict of interest.

\section{References}

1. Rabis, A.; Rodriguez, P.; Schmidt, T.J. Electrocatalysis for Polymer Electrolyte Fuel Cells: Recent Achievements and Future Challenges. ACS Catal. 2012, 2, 864-890. [CrossRef]

2. Costamagna, P.; Srinivasan, S. Quantum Jumps in the PEMFC Science and Technology from the 1960s to the Year 2000: Part I. Fundamental Scientific Aspects. J. Power Sources 2001, 102, 242-252. [CrossRef]

3. FCH2 JU 2017 AWP and Budget_FINAL-20122016-Clean (ID 2892681).Pdf. Available online: https:/ / www.fch.europa.eu/sites / default/files/FCH2\%20JU\%202017\%20AWP\%20and\%20Budget_FINAL-20122016-Clean\%20\%28ID\%202892681\%29_0.pdf (accessed on 18 May 2020).

4. Lèbre, É.; Stringer, M.; Svobodova, K.; Owen, J.R.; Kemp, D.; Côte, C.; Arratia-Solar, A.; Valenta, R.K. The Social and Environmental Complexities of Extracting Energy Transition Metals. Nat. Commun. 2020, 11, 4823. [CrossRef]

5. Publications Office of the European Union. EU Harmonised Test Protocols for PEMFC MEA Testing in Single Cell Configuration for Automotive Applications. Available online: http://op.europa.eu/en/publication-detail/-/publication/82c28cc6-cef7-11e5 -a4b5-01aa75ed71a1 (accessed on 18 May 2020).

6. Feng, Y.; Gago, A.; Timperman, L.; Alonso-Vante, N. Chalcogenide Metal Centers for Oxygen Reduction Reaction: Activity and Tolerance. Electrochim. Acta 2011, 56, 1009-1022. [CrossRef]

7. Higgins, D.C.; Hassan, F.M.; Seo, M.H.; Choi, J.Y.; Hoque, M.A.; Lee, D.U.; Chen, Z. Shape-Controlled Octahedral Cobalt Disulfide Nanoparticles Supported on Nitrogen and Sulfur-Doped Graphene/Carbon Nanotube Composites for Oxygen Reduction in Acidic Electrolyte. J. Mater. Chem. A 2015, 3, 6340-6350. [CrossRef]

8. Li, L.; Dai, P.; Gu, X.; Wang, Y.; Yan, L.; Zhao, X. High Oxygen Reduction Activity on a Metal-Organic Framework Derived Carbon Combined with High Degree of Graphitization and Pyridinic-N Dopants. J. Mater. Chem. A 2017, 5, 789-795. [CrossRef]

9. Zhang, L.; Wilkinson, D.P.; Liu, Y.; Zhang, J. Progress in Nanostructured (Fe or Co)/N/C Non-Noble Metal Electrocatalysts for Fuel Cell Oxygen Reduction Reaction. Electrochim. Acta 2018, 262, 326-336. [CrossRef]

10. Bashyam, R.; Zelenay, P. A Class of Non-Precious Metal Composite Catalysts for Fuel Cells. Nature 2006, 443, 63-66. [CrossRef]

11. Jaouen, F.; Proietti, E.; Lefèvre, M.; Chenitz, R.; Dodelet, J.-P.; Wu, G.; Chung, H.T.; Johnston, C.M.; Zelenay, P. Recent Advances in Non-Precious Metal Catalysis for Oxygen-Reduction Reaction in Polymer Electrolyte Fuel Cells. Energy Environ. Sci. 2010, 4, 114-130. [CrossRef] 
12. Villers, D.; Jacques-Bédard, X.; Dodelet, J.-P. Fe-Based Catalysts for Oxygen Reduction in PEM Fuel Cells Pretreatment of the Carbon Support. J. Electrochem. Soc. 2004, 151, A1507-A1515. [CrossRef]

13. Strickland, K.; Miner, E.; Jia, Q.; Tylus, U.; Ramaswamy, N.; Liang, W.; Sougrati, M.-T.; Jaouen, F.; Mukerjee, S. Highly Active Oxygen Reduction Non-Platinum Group Metal Electrocatalyst without Direct Metal-Nitrogen Coordination. Nat. Commun. 2015, 6, 7343. [CrossRef] [PubMed]

14. Weber, A.Z.; Borup, R.L.; Darling, R.M.; Das, P.K.; Dursch, T.J.; Gu, W.; Harvey, D.; Kusoglu, A.; Litster, S.; Mench, M.M.; et al. A Critical Review of Modeling Transport Phenomena in Polymer-Electrolyte Fuel Cells. J. Electrochem. Soc. 2014, 161, F1254-F1299. [CrossRef]

15. Asset, T.; Atanassov, P. Iron-Nitrogen-Carbon Catalysts for Proton Exchange Membrane Fuel Cells. Joule 2020, 4, 33-44. [CrossRef]

16. Beltrán, D.E.; Litster, S. Half-Wave Potential or Mass Activity? Characterizing Platinum Group Metal-Free Fuel Cell Catalysts by Rotating Disk Electrodes. ACS Energy Lett. 2019, 4, 1158-1161. [CrossRef]

17. Yin, X.; Lin, L.; Chung, H.T.; Babu, S.K.; Martinez, U.; Purdy, G.M.; Zelenay, P. Effects of MEA Fabrication and Ionomer Composition on Fuel Cell Performance of PGM-Free ORR Catalyst. ECS Trans. 2017, 77, 1273-1281. [CrossRef]

18. Malko, D.; Lopes, T.; Ticianelli, E.A.; Kucernak, A. A Catalyst Layer Optimisation Approach Using Electrochemical Impedance Spectroscopy for PEM Fuel Cells Operated with Pyrolysed Transition Metal-N-C Catalysts. J. Power Sources 2016, 323, 189-200. [CrossRef]

19. Stariha, S.; Artyushkova, K.; Workman, M.J.; Serov, A.; Mckinney, S.; Halevi, B.; Atanassov, P. PGM-Free Fe-N-C Catalysts for Oxygen Reduction Reaction: Catalyst Layer Design. J. Power Sources 2016, 326, 43-49. [CrossRef]

20. Babu, S.K.; Chung, H.T.; Zelenay, P.; Litster, S. Modeling Electrochemical Performance of the Hierarchical Morphology of Precious Group Metal-Free Cathode for Polymer Electrolyte Fuel Cell. J. Electrochem. Soc. 2017, 164, F1037-F1049. [CrossRef]

21. Banham, D.; Choi, J.-Y.; Kishimoto, T.; Ye, S. Integrating PGM-Free Catalysts into Catalyst Layers and Proton Exchange Membrane Fuel Cell Devices. Adv. Mater. 2019, 31, 1804846. [CrossRef]

22. Kongkanand, A.; Subramanian, N.P.; Yu, Y.; Liu, Z.; Igarashi, H.; Muller, D.A. Achieving High-Power PEM Fuel Cell Performance with an Ultralow-Pt-Content Core-Shell Catalyst. ACS Catal. 2016, 6, 1578-1583. [CrossRef]

23. Banham, D.; Kishimoto, T.; Zhou, Y.; Sato, T.; Bai, K.; Ozaki, J.; Imashiro, Y.; Ye, S. Critical Advancements in Achieving High Power and Stable Nonprecious Metal Catalyst-Based MEAs for Real-World Proton Exchange Membrane Fuel Cell Applications. Sci. Adv. 2018, 4, eaar7180. [CrossRef] [PubMed]

24. Chen, L.; Wu, G.; Holby, E.F.; Zelenay, P.; Tao, W.-Q.; Kang, Q. Lattice Boltzmann Pore-Scale Investigation of Coupled PhysicalElectrochemical Processes in C/Pt and Non-Precious Metal Cathode Catalyst Layers in Proton Exchange Membrane Fuel Cells. Electrochim. Acta 2015, 158, 175-186. [CrossRef]

25. Liu, J.; Talarposhti, M.R.; Asset, T.; Sabarirajan, D.C.; Parkinson, D.Y.; Atanassov, P.; Zenyuk, I.V. Understanding the Role of Interfaces for Water Management in Platinum Group Metal-Free Electrodes in Polymer Electrolyte Fuel Cells. ACS Appl. Energy Mater. 2019, 2, 3542-3553. [CrossRef]

26. Lopez-Haro, M.; Guétaz, L.; Printemps, T.; Morin, A.; Escribano, S.; Jouneau, P.-H.; Bayle-Guillemaud, P.; Chandezon, F.; Gebel, G. Three-Dimensional Analysis of Nafion Layers in Fuel Cell Electrodes. Nat. Commun. 2014, 5, 5229. [CrossRef] [PubMed]

27. Serov, A.; Artyushkova, K.; Niangar, E.; Wang, C.; Dale, N.; Jaouen, F.; Sougrati, M.-T.; Jia, Q.; Mukerjee, S.; Atanassov, P. Nano-Structured Non-Platinum Catalysts for Automotive Fuel Cell Application. Nano Energy 2015, 16, 293-300. [CrossRef] 